\title{
Isolation of Agrobacterium sp. BE516 from the Root of Miscanthus sacchariflorus and Its Plant Growth Promoting Activity
}

\author{
Hye-Young Kang $\cdot$ Dong-Jin Park $\cdot$ Jae-Chan Lee $\cdot$ Mi-Kyung Kwon $\cdot$ \\ Seung Bum Kim $\cdot$ Chang-Jin Kim

\section{물억새 뿌리로부터 Agrobacterium sp. BE516 균주의 분리 및 식물생육촉진활성}

강혜영· 박동진 · 이재찬 · 권미경 · 김승범 · 김창진

Received: 26 March 2012 / Accepted: 25 May 2012 / Published Online: 30 June 2012

(C) The Korean Society for Applied Biological Chemistry 2012

\begin{abstract}
To exploit plant growth promoting bacteria in the roots of Miscanthus sacchariflorus, a biomass energy crop, total 64 bacteria were isolated. For the investigation of plant growth promoting effects from the isolated bacteria, production of indole acetic acid (IAA) and 1-aminocyclopropane-1-carboxylic acid (ACC) deaminase activities were tested and other cultural conditions were examined. As results, 8 isolates showed plant growth promoting effects on the $M$. sacchariflorus and an isolate designated Agrobacterium sp. BE516 has the highest activity by enhancing the shoot elongation over 2-fold than the control. Agrobacterium sp. BE516 produced $64 \mu \mathrm{g}$ IAA per $\mathrm{mL}$ and showed ACC deaminase activity which is involved in the resistance to environmental stress such as high salt and drought. It could grow at low temperature in the range from 4 to $15^{\circ} \mathrm{C}$, at $\mathrm{pH}$ 4.0 and at $4 \% \mathrm{NaCl}$. These results indicate that the Agrobacterium sp. BE516 can be useful as a bio-fertilizer for M. sacchariflorus under the stressed conditions.
\end{abstract}

Keywords 1-aminocyclopropane-1-carboxylic acid deaminase ·

H.-Y. Kang · D.-J. Park · J.-C. Lee · M.-K. Kwon · C.-J. Kim ( $\square)$ Biological Resource Center, Korea Research Institute of Bioscience and Biotechnology, 125 Gwahak-ro, Yusong-gu, Daejeon 305-806, Republic of Korea

E-mail: changjin@kribb.re.kr

H.-Y. Kang · S. B. Kim

Department of Microbiology \& Molecular biology, School of Bioscience and Biotechnology, Chungnam National University, 220 Gung-dong, Yuseong, Daejeon 305-764, Republic of Korea indole acetic acid $\cdot$ Miscanthus sacchariflorus $\cdot$ plant growth promotion

\section{서 론}

억새는 화본과(Poacea)의 $\mathrm{C}_{4}$ 광합성 식물로서 영년생 작물이며 연간 biomass 생산량이 많고 비료 요구도가 낮으며 자연 상태 에서 병해충 발생도 거의 없어 바이오 연료용 원료작물로 각광 받고 있다(Christian과 Haase, 2001; Hodkinson과 Renvoize, 2001; Clifton-Brown 등, 2004; Heaton 등, 2006). 억새속 (Miscanthus)에는 참억새(Miscanthus sinensis), 물억새(Miscanthus sacchariflorus) 등 17 개 종이 있으며, 그 중 참억새는 내륙에 서 식하며 2 배체로서 염색체 수가 38 개이고, 물억새는 강가 및 호 수주변에 서식하며 4배체로서 염색체 수가 76개이며, 참억새와 물억새의 자연 교잡형인 Miscanthus X giganteus는 3배체로서 염색체 수가 57개로 알려져 있다(Lewandowski, 2000; CliftonBrown 등, 2004). 비식용 바이오매스 대상작물로 적합한 억새 를 우리나라에서 바이오 연료용 작물로 효율적으로 이용하기 위 해서는 비경작지에서의 대량 재배 가능성이 고려되어야 하므로 간척지나 척박지와 같은 조건불리지역에서의 억새 생육 촉진에 대한 연구가 필요하다. 식물의 생육촉진은 식물호르몬과 같은 생물학적 활성물질의 생산, 환경스트레스에 대한 저항성, 항균 활성물질 생산에 의한 식물병원균 확산억제 및 전신유도저항성 과 같은 식물면역반응 유도 기작 등에 의해 이루어진다. 따라 서, 본 실험에서는 간척지 및 강변 유휴지 등의 조건불리지역 에서 바이오매스 대상작물인 억새의 생육을 촉진시키기 위하여, 
물억새 뿌리로부터 근권미생물을 분리하고 식물 생장 촉진 효 과가 탁월한 균주를 선발하여 맞춤형 식물 생장 촉진 미생물 제제로 개발하는 기초시험 결과에 대해 보고하고자 한다.

\section{재료 및 방법}

시료 및 배지. 본 실험에서 사용한 억새 시료는 충북 청원군 대 청호에 서식하고 있는 물억새 10점을 채집하여 사용하였다. 내 생균 분리를 위해 Tryptone-Yeast extract agar (TYA) (1 L당 tryptone $5 \mathrm{~g}$, yeast extract $3 \mathrm{~g}, \mathrm{CaCl}_{2} 0.7 \mathrm{~g}$, agar $15 \mathrm{~g}, \mathrm{pH}$ 7.0) 와 R2A agar (Reasoner와 Geldreich, 1985) 배지를 사용 하였다.

내생세균의 분리. 대청호에서 채집한 물억새 뿌리 표면의 흙을 실험실 내에서 흐르는 수돗물을 이용하여 제거하고 증류수로 남 은 흙을 완전히 제거한 후 상온에서 건조시켜 뿌리 부위를 $1 \mathrm{~cm}$ 길이로 잘라냈다. 물억새 내생균의 분리를 위한 표면살균 은 Sheng 등(2009)의 방법을 사용하였다. 잘라낸 시료를 $4 \%$ $\mathrm{NaCl}$ 에 5 분, $2.5 \% \quad \mathrm{Na}_{2} \mathrm{~S}_{2} \mathrm{O}_{3}$ 에 10 분간 침지시킨 다음 멸균수로 4 회 세척하였고, $75 \%$ 에탄올에 3 분간 침지시킨 후, 멸균한 증 류수로 4회 세척한 다음 $10 \% \mathrm{NaHCO}_{3}$ 에 10 분간 침지시킨 후 건조시켜 억새표면에 존재하는 착생미생물(epiphyte)을 제거하는 과정을 수행하였다. 이때 마지막 세척액을 TYA 또는 R2A agar 배지에 도말하여 표면살균을 확인하는 대조구로 사용하였다. 표 면 살균한 시료는 멸균수와 함께 마쇄하여 적당량 희석한 후 배지에 도말하여 $28^{\circ} \mathrm{C}$ 에서 7 일간 배양하였고, 배지 상에 나타 난 군락을 각각의 배지에 옮겨 순수 분리하였다.

$16 \mathrm{SDNA}$ 유전자 염기서열 분석을 통한 분리균의 동정. 분리 된 세균의 genomic DNA 추출 및 $16 \mathrm{~S} \mathrm{rDNA}$ 유전자 증폭을 위해 Colony polymerase chain reaction (PCR) 방법(Hofmann 과 Brian, 1991; Waslsh 등, 1991)을 사용하였다. PCR은 universal primer인 27F (5'-AGA GTT TGA TCM TGG CTC AG-3') 와 1492R (5'-GGT ATC CTT GTT ACG ACT $\left.\mathrm{T}-3^{\prime}\right)$ 을 이용하였으며, $\mathrm{PCR}$ 반응농도는 $20 \mu \mathrm{L}$ 안에 $1 \times \mathrm{PCR}$ reaction buffer, 각각의 $2.5 \mathrm{mM}$ dNTPs, $10 \mathrm{pmol}$ 의 primer 그리고 2.5 unit의 $i$-StarTaq $^{\mathrm{TM}}$ DAN polymerase (iNtRON Biotechnology, Korea)를 사용하였다. 반응조건은 predenaturation $\left(94^{\circ} \mathrm{C}, 5 \mathrm{~min}\right)$, denaturation $\left(94^{\circ} \mathrm{C}, 1 \mathrm{~min}\right)$, annealing $\left(55^{\circ} \mathrm{C}, 1 \mathrm{~min}\right)$, extention $\left(72^{\circ} \mathrm{C}, 1 \mathrm{~min}\right)$ 으로 30 cycle을 수행한 후 $72^{\circ} \mathrm{C}$ 에서 10 분 동안 final extension을 수행하였다. 증폭된 PCR 산물들은 Ethidium bromide $(\mathrm{EtBr})$ 염색 후 $0.8 \%$ agarose gel에서 확인하였으며, Millipore PCR cleanup kit (Millipore Inc., USA)를 사용하여 정제하였고, $\mathrm{ABI}$ PRISM BigDye terminator cycle sequencing kit와 3730XL automated DNA sequencer (Perkin-Elmer, USA) 를 사용하여 염기서열을 결정하였다. 결정된 염기서열은 $\mathrm{NCBI}$ (www.ncbi.nlm.nih.gov)의 GenBank database로부터 BLAST 프 로그램(http://www.ncbi.nlm.nih.gov/BLAST/) 및 EzTaxon server (http://www.eztaxon.org/) (Chun 등, 2007)를 이용하여 염기서열 의 유사도를 분석하였다. ClustalW로 다중정렬을 수행하였고, Lasergene 5 (DNASTAR, USA)와 BioEdit 프로그램(Ver.7, Ibis Biosciences, USA)을 사용하여 염기서열을 정리하였으며, MEGA 5.0 (USA)프로그램의 Neighbor-Joining (NJ) 방법으로 분석하여 동일 균주의 중복을 배제하였다.

무균처리한 유묘로부터 억새생육촉진 세균의 선발. 분리된 세균
을 대상으로 억새 생육촉진 활성을 비교하였다. 물억새 종자의 표면살균은 대청호에서 채취한 물억새 종자를 $70 \%$ ethanol로 4 분, $2 \% \mathrm{NaClO}$ 에서 20 분 처리한 후 적당량의 멸균수로 4 차례 세척하는 방법을 사용하였고, 무균 상태에서 건조하여, 종자를 균주 현탁액에 1 시간 동안 침지하여 감염시킨 후 멸균한 Whatman paper No. 1 water plate (Petri dish; $87 \times 15 \mathrm{~mm}$ )에 올려 명(明)조건으로 $30^{\circ} \mathrm{C}$ 에서 7 일 동안 발아시켰다. 발아된 종 자 유묘를 멸균 상토 pot에 이식한 다음, 분리균주 현탁액 $\left(10^{8}\right.$ $\mathrm{CFU} / \mathrm{mL}$ )을 유묘 주위에 $10 \mathrm{~mL}$ 씩 분주하였다. 분리균주 현탁 액 대신 멸균수 $10 \mathrm{~mL}$ 씩을 동일하게 처리한 것을 대조구로 사 용하였으며, 각 처리구는 1 개체씩 3 반복 처리하여 배양 30 일 후 억새의 줄기 생장을 비교관찰하여 선별하였다.

식물호르몬 Auxin 생산능. 물억새 생장촉진활성을 보인 분리균 들에 대한 식물생장호르몬인 옥신 생산 능력을 실험하였다. 활 성은 King B $(\mathrm{KB})$ 배지를 사용하여 측정하였다 (Glickmann 과 Yves, 1995). KB배지 $100 \mathrm{~mL}$ 에 옥신 전구체인 L-tryptophan 을 $0.1 \%$ 첨가하고 분리균을 접종하여 $28^{\circ} \mathrm{C}$ 에서 24 시간 배양하 였다. 배양액을 $4^{\circ} \mathrm{C}$ 에서 $6,000 \mathrm{rpm}$ 으로 15 분간 원심분리하여 상 층액을 salkowski 용액 $\left(35 \% \quad \mathrm{HClO}_{4} \quad 50 \mathrm{~mL}, 0.5 \mathrm{M} \mathrm{FeCl}\right.$ $1 \mathrm{~mL}$ )과 $1: 2$ 로 30 분간 암실에서 반응시킨 다음 $540 \mathrm{~nm}$ 에서 흡 광도를 측정하였다(Gorden과 Weber, 1951). 균처리를 하지 않 은 것을 대조구로 사용하였으며, 시판 옥신 표준물질(IAA, indole-3-acetic acid)과 비교하여 옥신의 농도를 측정하여 정량 하였다.

환경스트레스 저항성 물질 1-aminocyclopropane-1-carboxylic acid (ACC) deaminase 생산능. 분리균의 간척지 토양의 건조, 염 등 환경 스트레스에 대한 저항성 유무를 알아보기 위하여 ACC deaminase 생산능을 조사하였다. Tryptic Soy Broth (TSB) 배지에 물억새 생장촉진활성을 보인 균주를 접종하여 $28^{\circ} \mathrm{C}$ 에서 24 시간 배양한 후 원심분리하여 균체를 회수하였다. 회수한 균 체는 $\mathrm{DF}$ salt minimal 배지로 깨끗이 씻은 다음, 질소원으로 3 $\mathrm{mM} \mathrm{ACC}$ 만을 첨가한 $\mathrm{DF}$ salt minimal 배지에 접종하여 $28^{\circ} \mathrm{C}$ 에서 48 시간 배양하였다. 대조구로는 $\mathrm{ACC}$ 를 첨가하지 않은 것 을 사용하였으며 $600 \mathrm{~nm}$ 에서 흡광도를 측정하여 $\mathrm{ACC}$ 이용에 따른 균체의 증가를 통해 ACC deaminase 생산을 판단하였다. 항진균성 siderophore 생산능. 항진균성 siderophore 생산성을 조사하기 위하여 CAS (chrome azurol S) blue agar 배지에 분 리균을 접종하여 $28^{\circ} \mathrm{C}$ 에 배양시키면서 오렌지색의 투명환 생성 유무를 관찰하여 siderophore 생산능을 측정하였다(Schwyn과 Neilans, 1987).

인산 가용화능. 난용성 인산염의 분해능을 조사하기 위해 LBcalcium phosphate agar배지(LB agar 배지에 $\mathrm{CaCl}_{2}$ 와 $\mathrm{K}_{2} \mathrm{HPO}_{4}$ 를 $0.5 \%$ 첨가)에 분리균을 도말하여 $28^{\circ} \mathrm{C}$ 에서 5 일간 배양하면 서 균체 주위에 인산용해 투명환 생성을 통해 분해능을 측정하 였다(Reva 등, 2004).

분리균의 식물병원균에 대한 길항력. 8 균주를 대상으로 억새 병해의 가능성이 있는 Fusarium 마름병에 대한 길항능을 조사 하였다. Fusarium oxysporum 과 Fusarium solani 를 $8 \mathrm{~mm}$ 크 기의 균체 $\operatorname{disk}$ 로 접종하여 $28^{\circ} \mathrm{C}$ 에서 2 일간 배양하고, 분리균 을 대치배양하여 $28^{\circ} \mathrm{C}$ 에서 5 일간 배양하면서 발육저지대 형성 유무로 항진균능을 측정하였다.

가수분해 효소활성. 진균세포벽 분해성 cellulose 활성 및 pectinase와 protease 활성을 조사하였다. Cellulase 활성은 basal

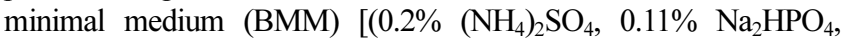




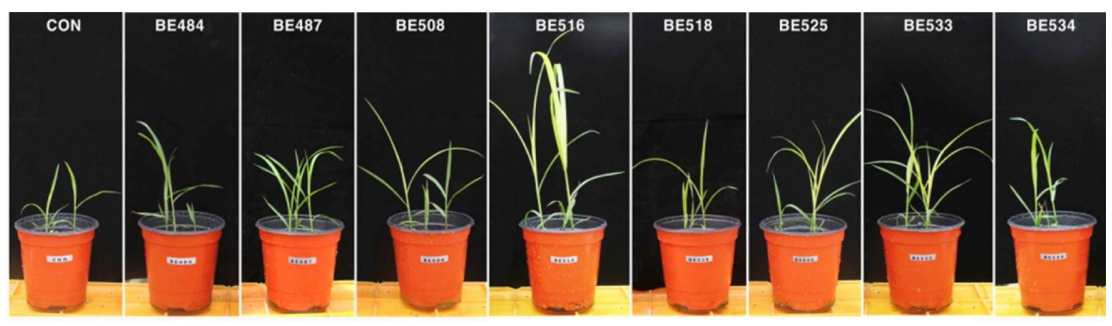

Fig. 1 Plant growth-promoting effects. Scale bars indicate shoot length of seedling in average 3 replications. Control; just treated with sterilized distilled water.

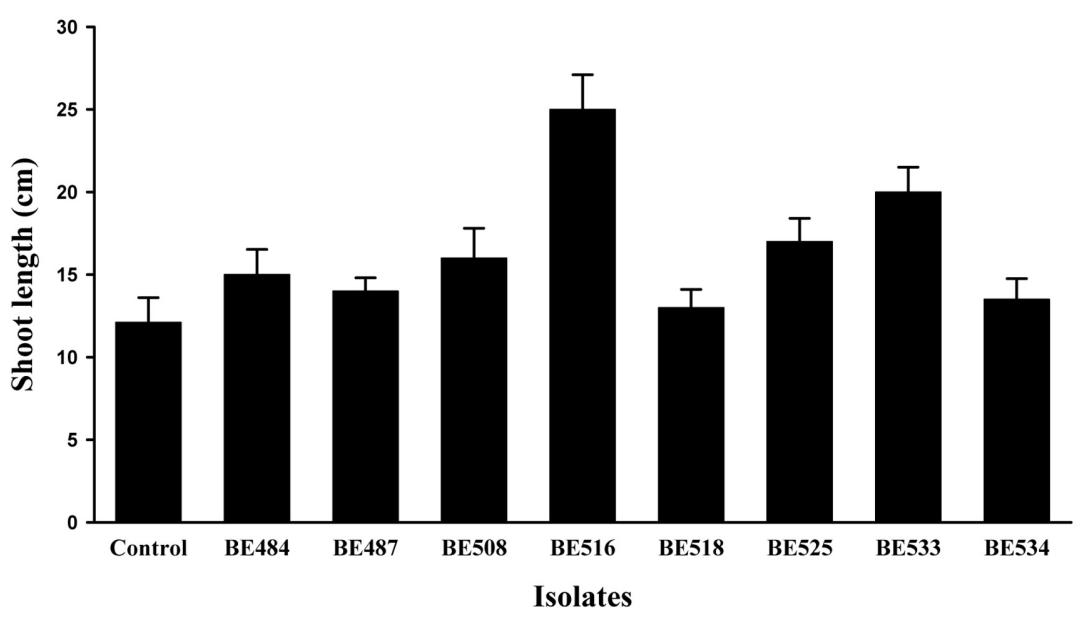

$0.07 \% \mathrm{KH}_{2} \mathrm{PO}_{4}, 0.0001 \% \mathrm{MgSO}_{4}, 0.0001 \% \mathrm{MnSO}_{4}$ ] 배지에 $0.4 \%$ Carboxymethyl cellulose $(\mathrm{CMC})$ 가 포함된 고체 배지에 시료를 분주하여 투명환 형성으로 활성을 확인하였고, pectinase 는 pectate lyase medium $[1 \%$ polygalacturonic acid, $1 \%$ yeast extract, $0.38 \mu \mathrm{M} \mathrm{CaCl}, 100 \mathrm{mM}$ Tris-HCl (pH 8.5), $0.8 \%$ agarose, $0.8 \%$ sodium azide]에 선발균주의 배양 상등액 을 분주하여 투명환 형성으로 활성을 확인하였으며, protease는 protease medium ( $3 \%$ gelatin 또는 skim milk, $0.4 \%$ nutrient broth, $0.8 \%$ agarose, $0.2 \%$ sodium azide)에 배양 상등액을 분 주하여 투명환 형성으로 활성을 확인하였다.

분리균의 다양한 환경조건에 대한 생육특성. 식물생장호르몬 (IAA)과 ACC deaminase를 생산하는 균주들에 대하여 기후 및 토양환경에 대한 적용성과 적응능을 알아보기 위하여 다양한 온 도, $\mathrm{pH}$ 및 염농도에서 균체의 생육능을 조사하였다. TY agar 평판배지를 사용하여 저온 $\left(4-15^{\circ} \mathrm{C}\right), \mathrm{pH}(\mathrm{pH} 4-6)$ 및 염농도 $(\mathrm{NaCl} 0.5-4 \%)$ 의 조건에서 3 일간 배양하여 대조구(TY agar medium at $28^{\circ} \mathrm{C}, \mathrm{pH} 7.0,0 \% \mathrm{NaCl}$ )와 생육정도를 비교하였다.

\section{결과 및 고찰}

물억새 내생세균의 분리 및 동정. 충북 청원군 대청호 주변의 물억새 10 점을 채집하여 뿌리를 표면 살균한 후 이로부터 64 종 의 내생균주를 분리하였다. 각 분리균주들은 $16 \mathrm{~S} \mathrm{rDNA}$ 부분유 전자 염기서열 $(1,400 \mathrm{bp}$ 이상)을 결정하여 BLAST분석 및 EzTaxon server를 이용하여 분리균의 동정 및 염기서열의 유사 도를 분석하였으며, Neighbor-Joining (NJ) 방법으로 phylogentic tree를 구성하여 분리균간의 동일균주를 파악한 후 분리균의 모 양 및 성상 등을 다시 비교확인 한 다음 동일균주로 판단되는
균주를 제외시켜 최종적으로 31종의 분리균주를 선별하였다(자 료미제시). 분리된 내생세균 31종은 분류상 Bacillus 19종, Lysinibacillus 3종 및 Agrobacterium, Brevibacterium, Burkholderia, Janthinobacterium, Microbacterium, Paenibacillus, Pasteurella, Pseudomonas, Renibacterium 속 균주가 각 1종으로 동정 되었다. 분리균주의 물억새 생장촉진 효과. 물억새 뿌리로부터 분리한 31 종의 분리균들에 대하여 생장촉진효과가 있는 균주를 분리하 기 위하여 물억새 유묘를 이용한 생장 촉진 효과를 조사하였으 며, 기주 식물에 어떠한 해로운 증상을 보이지 않는다는 내생 균의 특성(Reinhold와 Hurek, 1998)에 따라 분리균들에 대한 내 생성을 확인하는 방법으로 사용하였다. 물억새 뿌리로부터 분리 한 세균 현탁액에 물억새 종자를 침지처리 하였으며 발아된 종 자를 pot에 심어 30 일 동안 배양한 후 지상부의 길이를 측정하 였다. 미생물 당 3 개의 유묘를 사용하여 관찰하였고, 균을 처리 하지 않은 대조구와 비교하여 식물생장 촉진효과를 판단하였다. 31 종 가운데 8종의 분리균들이 평균 $10-100 \%$ 범위에서 물억 새 유묘의 줄기생장을 촉진하였고(Fig. 1) 특히, BE516 균주 처 리구는 $100 \%$ 이상의 탁월한 줄기신장 촉진효과를 보였으며, $16 \mathrm{~S} \mathrm{rDNA}$ 유전자 염기서열 $(1,451 \mathrm{bp})$ 분석결과 Agrobacterium vitis $\mathrm{NCPPB} 3554^{\mathrm{T}}$ (Accession no. D14502) 균주와 99.2\%의 염기서열 유사도를 나타내는 Agrobacterium 속 균주로 확인되 었고(Accession no. JQ764998), 나머지 균주들의 동정결과는 Table 1과 같다.

분리균의 식물호르몬 Auxin의 생성. 31종의 분리균 중 물억새 의 줄기생장촉진 효과를 나타낸 8 균주에 대하여 식물호르몬 생 산 여부를 조사하였다. 8 균주의 IAA생산량은 최소 $18.91 \mu \mathrm{g}$ / $\mathrm{mL}$ 에서 최대 $64.32 \mu \mathrm{g} / \mathrm{mL}$ 이었으며 그 중 Agrobacterium $\mathrm{sp}$. $\mathrm{BE} 516$ 이 가장 많은 양을 생산하였다(Table 2). 옥신은 대표적인 식물생장촉진호르몬으로써 식물에서 줄기 신장 생장 촉진, 뿌리 
Table 1. Identification of plant growth-promoting bacteria isolated from the root of Miscanthus sacchariflorus by $16 \mathrm{~S}$ rDNA sequencing

\begin{tabular}{|c|c|c|}
\hline Isolates & Closest type strain name (accession no.) & Similarity* \\
\hline BE484 & $\begin{array}{l}\text { Bacillus subtilis subsp. inaquosorum } \text { BGSC } 3 \mathrm{~A} 28^{\mathrm{T}} \\
\text { (EU138467) }\end{array}$ & $98.6 \%$ \\
\hline BE487 & Bacillus simplex NBRC $15720^{\mathrm{T}}(\mathrm{AB} 363738)$ & $98.1 \%$ \\
\hline BE508 & $\begin{array}{l}\text { Bacillus thuringiensis ATCC } 10792^{\mathrm{T}} \\
\text { (ACNF01000156) }\end{array}$ & $98.9 \%$ \\
\hline BE516 & Agrobacterium vitis NCPPB $3554^{\mathrm{T}}$ (D14502) & $99.2 \%$ \\
\hline BE518 & Paenibacillus terrigena $\mathrm{A} 35^{\mathrm{T}}$ (AB248087) & $99.0 \%$ \\
\hline BE525 & Pseudomonas moorei $\mathrm{RW} 10^{\mathrm{T}}$ (AM293566) & $96.7 \%$ \\
\hline BE533 & Lysinibacillus xylanilyticus XDB9 ${ }^{\mathrm{T}}$ (FJ477040) & $100.0 \%$ \\
\hline BE534 & Bacillus bataviensis LMG $21833^{\mathrm{T}}(\mathrm{AJ} 542508)$ & $99.7 \%$ \\
\hline
\end{tabular}

*Sequence similarity values were computed using the ClustalW program.

형성 촉진, 세포분열촉진 등과 같은 생리 작용을 가지고 있어 식물이 생장하는데 도움을 주며 억새 유래 미생물들이 옥신 호 르몬을 생산함으로써 억새 생장을 촉진시키는데 도움을 줄 것 으로 사료된다.

환경스트레스 저항성 물질 ACC deaminase 의 생성. 31종의 내생세균 중 물억새의 지상부 생장촉진효과를 보였던 8 균주에 대하여 ACC deaminase 생산 여부를 조사하였다. ACC deaminase 생산은 분리균들이 질소원으로 $\mathrm{ACC}$ 만을 첨가한 배지에서 생육 하는지의 여부를 보고 판단하였다. 그 결과, 8 균주 모두 $\mathrm{ACC}$ 만을 질소원으로한 배지에서 생장하였으며, BE516, B508 및 $\mathrm{BE} 533$ 균주의 ACC deaminase 생산능이 좋았다(Fig. 2). ACC 분해효소인 ACC deaminase를 생산하는 미생물은 식물뿌리내에 서 스트레스 물질 에틸렌의 전구체인 $\mathrm{ACC}$ 농도를 감소시켜 결 과적으로 에틸렌의 합성을 줄임으로서 식물의 생장을 촉진시키 는 작용을 하므로 본 연구에서 선발된 균주가 건조 및 고염 조 건의 척박토양에서 식물이 잘 자랄 수 있게 할 뿐만 아니라 간 척지 등에 노출되어 있는 환경스트레스도 완화할 수 있을 것으 로 사료된다.

기타 식물생육촉진 활성. 식물병원균 확산억제 기작관련 siderophore 생성능, 식물병원균에 대한 길항능, 불용성 인산 가
Table 2. Production of IAA by plant growth-promoting bacteria isolated from the root of $M$. sacchariflorus

\begin{tabular}{cccc}
\hline Isolates & $\begin{array}{c}\text { Concentration of IAA } \\
(\mu \mathrm{g} / \mathrm{mL})^{*}\end{array}$ & Isolates & $\begin{array}{c}\text { Concentration of IAA } \\
(\mu \mathrm{g} / \mathrm{mL})\end{array}$ \\
\hline BE484 & $35.87 \pm 0.13$ & BE518 & $18.91 \pm 0.10$ \\
BE487 & $23.51 \pm 0.09$ & BE525 & $42.23 \pm 0.61$ \\
BE508 & $39.27 \pm 0.45$ & BE533 & $51.24 \pm 0.54$ \\
BE516 & $64.32 \pm 0.65$ & BE534 & $20.81 \pm 0.07$ \\
\hline
\end{tabular}

*IAA was estimated at $24 \mathrm{~h}$ after the bacterial growth in King B medium supplemented with $0.1 \%$

용화능 및 병원균 세포벽 분해효소 활성을 조사하였다. BE516 균주에서 protease 활성을 보이는 것을 외에는 8 균주 모두 상 기 생성능 및 활성은 보이지 않았다(자료미제시).

분리균의 스트레스 환경조건에 대한 생장능. 8 균주들에 대하여 스트레스 환경 조건에 대한 생육 여부를 조사하였다. 저온에서 는 대조구와 비교하여 BE516, BE508 및 BE533 균주가 생육 하였고, 산성조건에서는 $\mathrm{BE} 516$ 균주만 생육하였으며, $\mathrm{NaCl}$ 농 도에서는 $0.5-2 \% \mathrm{NaCl}$ 까지는 모두 생육하였으나 $3 \%$ 에서는 5 균주만 생육하였고 4\%에서는 BE516 균주만 생육하였다. 이같 은 결과는 우리나라 연근해의 바닷물의 농도가 $3 \%$ 정도 유지하 고 있으므로 본 연구에서의 BE516 균주가 간척지 등의 염해지 역에 적용하기에 적합하다고 사료되며 환경스트레스 저항성 물 질인 ACC deaminase 생성능과 일치되는 결과를 보여주었다 (Table 3).

따라서, 물억새 뿌리에서 분리한 내생세균으로부터 억새생장 촉진활성을 확인하여 선발한 8 균주 중 Agrobacterium sp. $\mathrm{BE} 516$ 균주가 조건불리지역에서의 활용성을 고려할 때 가장 뛰 어난 활성을 지닌 균주로 선발되었다. Agrobacterium sp. $\mathrm{BE} 516$ 균주는 식물호르몬 옥신을 생산하고, 스트레스 저항성 물질인 $\mathrm{ACC}$ 를 분해하는 $\mathrm{ACC}$ deaminase를 생산하며 protease 활성을 가지고 있으며, $4^{\circ} \mathrm{C}, \mathrm{pH} 4.0$ 및 $4 \% \mathrm{NaCl}$ 농도까지 생 육하는 등 간척지와 같은 조건 불리지역에서 비식용 바이오매 스 대상작물인 억새의 생육을 촉진시키기 위한 미생물비료제 개 발에 적합한 균주로 판단된다.

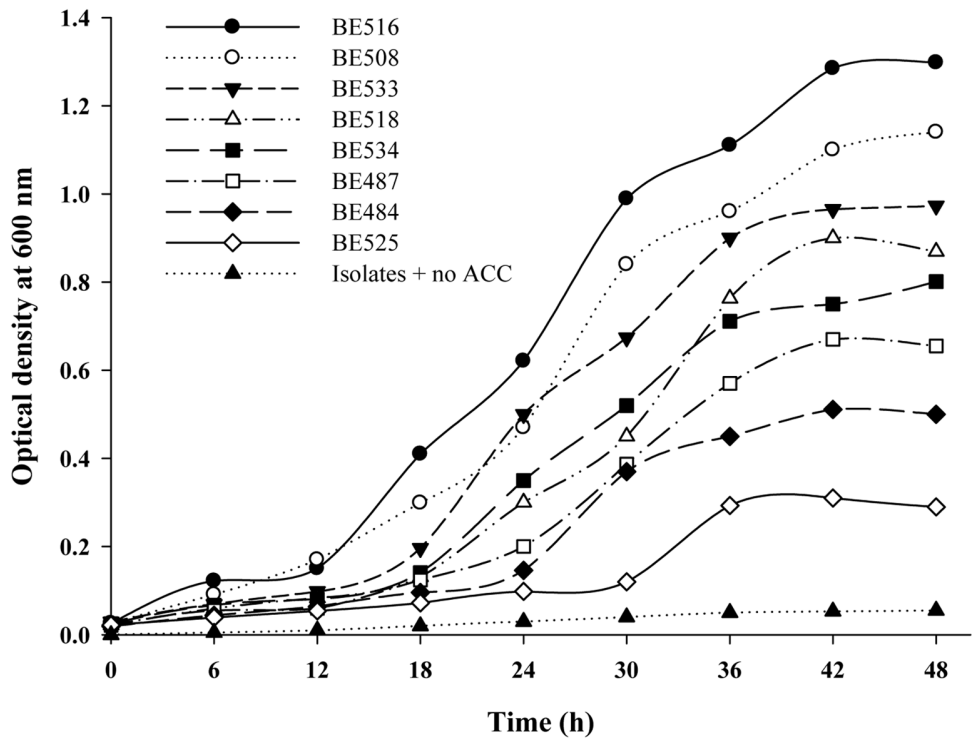

Fig. 2 Production of ACC deaminase from selected isolates (growth on ACC as sole nitrogen source). Control; each isolate + DF salt minimal media + no ACC. O.D is the mean value on each isolate in control growth curve. 
Table 3. Effects of isolates on growth at the stress conditions

\begin{tabular}{|c|c|c|c|c|c|c|c|c|c|c|c|c|}
\hline \multirow{2}{*}{ Isolates } & \multirow{2}{*}{ Con. } & \multicolumn{3}{|c|}{ Temperature $\left({ }^{\circ} \mathrm{C}\right)$} & \multicolumn{3}{|c|}{$\mathrm{pH}$} & \multicolumn{5}{|c|}{$\mathrm{NaCl}(\mathrm{w} / \mathrm{v}, \%)$} \\
\hline & & 4 & 10 & 15 & 4.0 & 5.0 & 6.0 & 0.5 & 1.0 & 2.0 & 3.0 & 4.0 \\
\hline BE484 & +++ & - & + & ++ & - & - & + & +++ & ++ & + & - & - \\
\hline BE487 & +++ & - & - & ++ & - & + & ++ & +++ & ++ & ++ & - & - \\
\hline BE508 & +++ & + & ++ & +++ & - & + & +++ & +++ & +++ & +++ & ++ & - \\
\hline BE516 & +++ & ++ & +++ & +++ & + & ++ & +++ & +++ & +++ & +++ & +++ & + \\
\hline BE518 & +++ & - & + & +++ & - & + & +++ & +++ & +++ & ++ & + & - \\
\hline BE525 & +++ & - & - & + & - & - & + & +++ & ++ & + & - & - \\
\hline BE533 & +++ & + & ++ & ++ & - & ++ & +++ & +++ & +++ & ++ & + & - \\
\hline BE534 & +++ & - & + & + & - & - & + & +++ & ++ & ++ & + & - \\
\hline
\end{tabular}

+++: good, ++: medium, +: week, -: no growth

Con.: TY agar medium at $28, \mathrm{pH} 7.0,0 \% \mathrm{NaCl}$

\section{초 록}

비식량 바이오매스 대상작물인 억새의 생육을 촉진하는 균주를 선발하기 위하여 충북 청원군 대청호 주변에서 서식하는 물억 새 뿌리로부터 64 균주를 분리하였다. 분리균의 식물생육촉진 활 성을 확인하기 위하여 옥신, 1-aminocyclopropane-1-carboxylic acid (ACC) deaminase 생선능 및 기타 배양조건에 따른 생육 특성을 조사한 결과, 8 균주가 선발되었으며 Agrobacterium sp. $\mathrm{BE} 516$ 균주가 억새 줄기의 생육을 2배 이상 증가시켜 가장 활 성이 뛰어난 균주로 선발되었다. Agrobacterium sp. BE516 균 주는 식물호르몬 indole acetic acid를 $64 \mu \mathrm{g} / \mathrm{mL}$ 생산하고, 염 및 건조 등의 환경 스트레스 저항성 $\mathrm{ACC}$ deaminase 를 생산 하며, $4-15^{\circ} \mathrm{C}, \mathrm{pH} 4.0$ 및 $4 \% \mathrm{NaCl}$ 농도에서 생육하였다. 따 라서, Agrobacterium sp. BE516 균주가 간척지와 같은 조건불 리지역에서 비식용 바이오매스 대상작물인 억새의 생육을 촉진 시키기 위한 미생물비료제 개발에 유용한 균주임을 확인하였다.

Keywords 1-aminocyclopropane-1-carboxylic acid deaminase indole acetic acid $\cdot$ Miscanthus sacchariflorus $\cdot$ plant growth promotion

감사의 글. 본 연구는 농림수산식품연구개발사업과 KRIBB 주요사업의 연구 비 지원에 의하여 수행되었으며, 이에 감사 드립니다.

\section{참고문헌}

Christian DG and Haase E (2001) Agronomy of miscanthus. In Miscanthus for Energy and Fiber. Jones MB, Walsh M (eds.), pp. 33-8, James and James (science Publishers) Ltd., UK.

Chun J, Lee JH, Jung Y, Kim M, Kim S, Kim BK, and Lim YW (2007) EzTaxon: a web-based tool for the identification of prokaryotes based on 16S ribosomal RNA gene sequences. Int J Syst Evol Microbiol 57,
2259-61.

Clifton-Brown JC, Stampfl PF, and Jones MB (2004) Miscanthus biomass production for energy in Europe and its potential contribution to decreasing fossil fuel carbon emissions. Global Change Biol 10, 509-18.

Glickmann E and Yves D (1995) A critical examination of the specificity of the salkowski reagent for indolic compounds produced by phytopathogenic bacteria. Appl Environ Microbiol 61, 793-6.

Gorden SA and Weber RP (1951) Colorimetric estimation of indole acetic acid. Plant physiol 26, 192-5.

Heaton EA, Voigt TB, and Long SP (2006) In Miscanthus $x$ giganteus: The Results of Trials Alongside Switchgrass (Panicum virgatum) in Illinois. University of Illinois at Urbana-Champaign: Department of Plant Biology, USA.

Hodkinson TR and Renvoize S (2001) Nomenclature of Miscanthus xgiganteus (Poaceae). Kew Bulletin 56, 759-60.

Hofmann MA and Brian DA (1991) Sequencing PCR DNA amplified directly from a bacterial colony. Biotechniques 11, 30-1.

Lewandowski I, Clifton-Brown JC, Scurlock JMO, and Huisman W (2000) Miscanthus: European experience with a novel energy crop. Biomass Bioeng 19, 209-27.

Reasoner DJ and Geldreich EE (1985) A new medium for the enumeration and subculture of bacteria from potable water. Appl Environ Microbiol 49, 1-7.

Reinhold-Hurek B and Hurek T (1998) Life in grasses: diazotrophic endophytes. Trends Microbiol 6, 139-44.

Reva ON, Dixelius C, Meijer J, and Priest FG (2004) Taxonomic characterization and plant colonizing abilities of some bacteria related to Bacillus amyloliquefaciens and Bacillus subtilis. FEMS Microbiol Ecol 48, 249-59.

Schwyn B and Neilans JB (1987) University chemical assay for the detection and determination of siderophores. Anal Biochem 160, 46-52.

Sheng Qin, Jie Li, Hua-Hong Chen, Guo-Zhen Zhao, Wen-Yong Zhu, ChengLin Jiang et al. (2009) Isolation, diversity, and antimicrobial activity of rare actinobacteria from medicinal plants of tropical rain forests in Xishuangbanna, China. Appl Environ Microbiol 75, 6176-86.

Walsh P, Metzger D, and Higuchi R (1991) Chelex 100 as a medium for simple extraction of DNA for PCR-based typing from forensic material. Biotechniques 10, 506-13. 